\title{
Study on the gelatinization properties and amylose content of rice varieties from Nigeria and Cameroun
}

\author{
Amaka M. Odenigbo ${ }^{1,2}$, Michael Ngadi ${ }^{1,}$, , Chijioke Ejebe ${ }^{1}$, Chijioke Nwankpa ${ }^{1}$, \\ Nahemiah Danbaba ${ }^{3}$, Sali Ndindeng ${ }^{4}$, John Manful ${ }^{5}$ \\ ${ }^{1}$ Department of Bioresource Engineering, McGill University, 21111 Lakeshore Road, Ste-Anne-de-Bellevue, Quebec, H9X 3V9 Canada \\ ${ }^{2}$ Department of Human Nutrition and Dietetics, Michael Okpara University of Agriculture, Umudike, Nigeria \\ ${ }^{3}$ NCRI, Badeggi, Nigeria \\ ${ }^{4}$ IRAD, Yaounde, Cameroun \\ ${ }^{5}$ AfricaRice, Cotonu, Benin
}

\section{Email address:}

michael.ngadi@mcgill.ca(M. Ngadi)

\section{To cite this article:}

Amaka M. Odenigbo, Michael Ngadi, Chijioke Ejebe, Chijioke Nwankpa, Nahemiah Danbaba, Sali Ndindeng, John Manful. Study on the Gelatinization Properties and Amylose Content of Rice Varieties from Nigeria and Cameroun. International Journal of Nutrition and Food Sciences. Vol. 2, No. 4, 2013, pp. 181-186. doi: 10.11648/j.ijnfs.20130204.14

\begin{abstract}
Thirteen varieties (improved and local varieties) of non-parboiled milled rice (Oryza sativa Linn) grown in Nigeria and Cameroun were screened for gelatinization and amylose profile. Differential Scanning Calorimeter (DSC) was used in determining the gelatinization enthalpy $(\Delta H)$, onset $(T \mathrm{o})$, peak $(T \mathrm{p})$ and conclusion $(T \mathrm{c})$ temperatures. Results from DSC curves presented a single endothermic transition and a flow of maximum heating at peak temperatures from 67.66 and $81.27{ }^{\circ} \mathrm{C}$.The enthalpy levels varied from $0.33 \mathrm{~J} / \mathrm{g}$ for Panter, to $2.90 \mathrm{~J} / \mathrm{g}$ for Jamila. Amylose content varied from $8.59 \%$ for FARO 57, to $23.61 \%$ for TOX 3145. Comparing samples of local varieties with those of improved varieties showed higher values for onset and peak gelatinization temperatures among local varieties. A significant and positive correlation was observed in onset temperature, peak and conclusion temperatures while amylose was negatively and weakly related to all gelatinization parameters.
\end{abstract}

Keywords: Non-Parboiled Rice, Improved Rice, Local Rice, Gelatinization, Amylose, DSC

\section{Introduction}

Hybridization between the two domesticated/cultivated rice species; Oryza sativa Linn and Oryza glaberrima Steud for desirable agronomic characteristics led to the production of New Rice for Africa known as NERICA [1,2]. Presently in Africa, there are several newly improved breeding lines, which are grown along with the previously cultivated varieties [3].

These numerous rice varieties in Africa have wide genetic variation [4].

The gene trait inherited from parental specie has been associated to amylose content in rice varieties. Kishine et al. [5] reported that NERICA varieties with gene inheritance from $O$. glaberrima had high amylose content while the varieties with gene from inheritance from the $O$. sativa lines had lower amylose content. Rice classification based on amylose content was described by Lawal et al. [6] as follows; waxy (0-2 \% amylose), very low amylose $(2-12 \%)$, low amylose $(12-20 \%)$, intermediate amylose (20-25\%) and high amylose (25$33 \%)$.

Amylose and amylopectin are two glucose polymers in starch granules [6]. Amylose is essentially linear, consist of $\alpha-(1,4)$-linked D-glucopyranosyl units while amylopectin is highly branched and made up of $\alpha$-(1,4)-linked Dglucopyranosyl units joined through $\alpha-(1,6)$ linkages [7].

Approximately, $90 \%$ of milled rice (dry matter) comprised of starch and the eating as well as cooking quality of rice is influenced by the starch characteristics, which include amylose content, gelatinization temperatures [8].

Quantifying gelatinization characteristics of food is very relevant in food processing because it allows simulation of the cooking process for improved functional properties $[8,9]$.

Amylose tends to act as a restraint to gelatinization because it diffuses out of the granules during swelling, making up the continuous phase (network) outside the 
granules [10]. It has been reported that waxy starches usually swell to a greater extent than non-waxy starches [11, $12]$.

Varavinit et al. [11] reported a positive correlation of amylose to onset, peak and conclusion temperatures $(0.84$, 0.88 , and 0.85 , respectively). Their study suggested the prediction of amylose content of rice with gelatinization properties. A similar result by Park et al. [13] stated that gelatinization temperatures increase with higher amylose content in rice starches. Park et al. [13] postulated that the crystalline regions of non-waxy (high amylose) rice starch restricted the hydration of amorphous regions whereas waxy (high amylopectin) rice starch consisted mostly of crystalline regions and thus could begin gelatinization at a lower temperature.

Differential Scanning Calorimeter (DSC) has been used extensively to describe the gelatinization properties of rice flour. Normand and Marshall [14] demonstrated only one endothermic transition during gelatinization milled rice flour whereas milled whole grain rice exhibited two endothermic transitions.

This study therefore, aimed at using DSC in screening the gelatinization properties of selected improved and local rice varieties among the popular non-parboiled, milled rice in Nigeria and Cameroun.

\section{Materials and Methods}

\subsection{Samples}

Rice varieties are Japonica subspecies, crossed between two Oryza sativa parents. The improved varieties are improved lines of Oryza sativa $L$ originated from AfricaRice Center, Benin. Samples from Nigeria were five improved varieties (FARO 44, FARO 57, FARO 60, FARO 61) obtained from the Breeding Unit of Rice Research Program, National Cereal Research Institute (NCRI) Badeggi and four local varieties (Kwandala, Yardass, Jeep, Jamila) obtained from crop improvement unit of Kano State Agriculture and Rural Development Agency (KNARDA). From Cameroun, two improved varieties (TOX 3145, NERICA-3) and two local varieties (Panter, Tianan) were collected from a rice farmer in Ndop, Northwest Region of Cameroun.

Panicle picking was used in harvesting the samples and afterward samples were dried to $12 \%$ moisture content before manually threshed and cleaned. The samples were dehulled using a rice dehuller(THU 35A, Satake, Engineering Co. Ltd., Tokyo) before milling (McGill mill, Model No. 2, Brookshire, Texas) for 30 seconds.

\subsection{Sample Preparation for Analysis}

Grains of the rice samples were individually ground using a coffee grinder (SUMEET Multi Grind, India) and passed through a $0.5 \mathrm{~mm}$ sieve (CETyler, Ontario, Canada).

\subsubsection{Isolation of Starch}

Starch was extracted from rice flour samples by alkaline deproteination method according to Lim et al. [15] with slight modification. About $100 \mathrm{~g}$ of flour was mixed with $300 \mathrm{ml}$ of $0.5 \% \mathrm{NaOH}$. The mixture was constantly stirred for $4 \mathrm{~h}$ and left to stand for $24 \mathrm{~h}$ at $10{ }^{\circ} \mathrm{C}$. The supernatant was decanted and the solid phase washed several times with distilled water until the $\mathrm{pH}$ of the filtrate was between 6.0 and 6.5. The isolated starch was ovendried at $40{ }^{\circ} \mathrm{C}$ for $48 \mathrm{~h}$ and later ground in a motar to pass though a $0.55 \mathrm{~mm}$ mesh sieve, then used for amylose determination.

\subsection{Gelatinization}

The gelatinization properties were examined by a Differential Scanning Calorimeter (DSC Q100, TA instruments, Wilmington, DE, USA). Heat flow and temperature calibrations of the DSC were performed using pure indium with $28.41 \mathrm{~J} / \mathrm{g}$ heat of fusion and a melting temperature of $156.66{ }^{\circ} \mathrm{C}$. The experimental values were within $\pm 3 \%$ of the literature value.

A mass of $3 \pm 0.01 \mathrm{mg}$ was carefully placed at the centre of a pre weighed aluminium pan $(40 \mu \mathrm{l})$. Considering the moisture content of each sample, appropriate volume of distilled water was added to the pan by a micropipette to achieve a flour/ water ratio of 1: 2. This ratio of $1: 2$ accounts for more than $60 \%$ moisture, which is the moisture content required for rice gelatinization and to obtain a single endotherm during DSC experiment [16]. The pans were hermetically sealed with TA sample encapsulating press. The sealed pans were stored at room temperature to stabilize for one hour before analysis. The sample pans were placed in the sample cells while an empty pan was placed in the reference cell of the DSC. Samples were heated from 35 to $100{ }^{\circ} \mathrm{C}$ at a rate of $10{ }^{\circ} \mathrm{C} / \mathrm{min}$. The onset (To), peak (Tp) and conclusion (Tc) temperatures of gelatinization were determined. Gelatinization enthalpy $(\Delta \mathrm{H})$ was measured in $\mathrm{J} / \mathrm{g}$ of dried sample weight.

\subsection{Amylose Determination}

The analytical procedure of Hoover and Ratnayake [17] was adopted in determination of amylose content. Isolated starch $(20 \mathrm{mg})$ derived from procedure in 2.2.1 was vortexed with $8 \mathrm{ml}$ of $90 \%$ dimethylsulfoxide (DMSO) then incubated in a shaking water bath at $85^{\circ} \mathrm{C}$ for $15 \mathrm{~min}$. Solution was subsequently cooled at room temperature for $45 \mathrm{~min}$ then diluted with distilled and deionized water (DDW) to $25 \mathrm{ml}$. Aliquot of $1 \mathrm{ml}$ from the diluted solution was added to $40 \mathrm{ml}$ of DDW then mixed vigorously with 5 $\mathrm{ml}$ of iodine solution ( $0.0025 \mathrm{M} \mathrm{I} / 0.0065 \mathrm{M} \mathrm{KI}$ mixture). Afterward volume was adjusted to $50 \mathrm{ml}$ with DDW, mixed vigorously and allow to develop colour for $15 \mathrm{~min}$. Absorbance was measured at $600 \mathrm{~nm}$ against a reagent blank. The percentage of amylose was calculated from an 
equation obtained from the standard curve.

\subsection{Statistical Analysis}

Data were subjected to one way analysis of variance (ANOVA) followed by Fisher's least significant-difference (LSD) test $(P<0.05)$ to determine the differences in amylose contents and gelatinization parameters among the thirteen samples. Results were expressed as mean \pm standard deviation of three replicates. Independent T-test was performed for differences in amylose contents and gelatinization parameters between local and improved rice varieties. The statistical software used was SAS version 9.3 (SAS Institute Inc., Cary, NC, USA). A dendrogram was drawn using UnscramblerX version 10.3 (CAMO Software AS, Oslo, Norway) for cluster analysis.

\section{Results and Discussion}

Gelatinization properties of improved and local rice varieties obtained from DSC curves presented single endothermic transition (Fig. 1 and 2, respectively). The displayed endotherm curves confirmed an earlier report that milled rice flour exhibit only one endothermic transition during gelatinization [14].

Gelatinization parameters and amylose content showed significant variation among samples (Table 1). The gelatinization temperatures ranged from 63.42 to $78.34^{\circ} \mathrm{C}$ for onset temperature; 67.66 to $81.27^{\circ} \mathrm{C}$ for peak temperature; and from 72.03 to $90.18{ }^{\circ} \mathrm{C}$ for conclusion temperature. This result is similar to those reported by previous studies $[4,14,18]$. The study on 39 milled rice samples from West Africa reported ranges for onset temperature from 58 to $72{ }^{\circ} \mathrm{C}$; peak from 66 to $77^{\circ} \mathrm{C}$ and conclusion temperature from 70 to $83{ }^{\circ} \mathrm{C}$ [4].

Highest peak temperature $\left(81.27^{\circ} \mathrm{C}\right)$ was found in FARO 57 which also had the lowest amylose $(8.59 \%)$. This implies high content of amylopectin in FARO 57 sample in this study. This result agrees with the finding of highest peak temperature among waxy rice samples in an earlier study by Zhu et al. [19]. Peak temperature represents half the conversion temperature of sample melting.

The lowest onset and peak temperatures with highest amylose content $(23.61 \%)$ was found in TOX 3145 . This finding is contrary to the positive correlation of amylose to onset, peak and conclusion temperatures reported by Park et al. $[11,13]$. This finding suggests that other factors such as starch structures, nutritional composition could have influenced the gelatinization of non-parboiled rice

The low enthalpy from 0.33 to $2.90 \mathrm{~J} / \mathrm{g}$ found among samples in this present study is comparable to the enthalpy data (from 0.58 to $4.21 \mathrm{~J} / \mathrm{g}$ ) reported on rice varieties from West Africa [4]. Fan et al. [18] reported that non-starch components in rice flour such as protein, ash, fiber and lipids reduce enthalpy for gelatinization. Saif et al. [20] stated that starch concentration and varied level of water / starch ratio have significant influence on gelatinization properties of rice flour.

Low enthalpy values were also attributed to low molecular weight and chain length distribution of amylopectin [21]. This indicates the need for further study on starch structure of these non-parboiled rice samples in our study.

According to food classification based on amylose content [6], only FARO 57 and TOX 3145 had very low amylose $(8.59 \%)$ and intermediate amylose $(23.61 \%)$, respectively. The other samples showed low amylose content $(12$ to $<20 \%)$. The observed levels of amylose are consistent with data in previous studies on milled rice varieties $[22,23]$. Almost all samples studied by Bocevska et al.[22] had low amylose content (12-19.4\%) with exception of one variety that had intermediate amylose content $(23.3 \%)$. Similarly, amylose values between $2.3 \%$ and $15.4 \%$ were found among milled rice varieties involved in a study by Singh et al. [23].

The variation in amylose classification among samples between very low to intermediate agrees with literature that amylose content in rice is influenced by variety [24, 25].

Table 1. Gelatinization properties and amylose content of non-parboiled rice varieties

\begin{tabular}{llllll}
\hline Rice varieties & To $\left({ }^{\circ} \mathbf{C}\right)$ & $\mathbf{T p}\left({ }^{\circ} \mathbf{C}\right)$ & Tc $\left({ }^{\circ} \mathbf{C}\right)$ & $\Delta \mathbf{H}(\mathbf{J} / \mathbf{g})$ & Amylose (\%) \\
\hline Improved & & & & & \\
FARO 44 & $63.50 \pm 2.06 \mathrm{f}$ & $69.28 \pm 1.48 \mathrm{e}$ & $79.66 \pm 0.78 \mathrm{f}$ & $2.51 \pm 0.32 \mathrm{ab}$ & $16.54 \pm 1.47 \mathrm{bc}$ \\
FARO 52 & $63.74 \pm 0.55 \mathrm{ef}$ & $68.79 \pm 0.28 \mathrm{e}$ & $77.70 \pm 1.10 \mathrm{f}$ & $1.54 \pm 0.74 \mathrm{cde}$ & $15.86 \pm 1.16 \mathrm{bc}$ \\
FARO 57 & $76.47 \pm 0.51 \mathrm{~b}$ & $81.27 \pm 0.44 \mathrm{a}$ & $89.55 \pm 0.47 \mathrm{ab}$ & $2.13 \pm 0.06 \mathrm{bc}$ & $8.59 \pm 1.24 \mathrm{~d}$ \\
FARO 60 & $76.97 \pm 0.17 \mathrm{ab}$ & $80.31 \pm 0.12 \mathrm{ab}$ & $90.18 \pm 2.74 \mathrm{a}$ & $1.17 \pm 0.01 \mathrm{ef}$ & $18.49 \pm 2.01 \mathrm{ab}$ \\
FARO 61 & $78.34 \pm 0.37 \mathrm{a}$ & $81.22 \pm 0.35 \mathrm{a}$ & $87.86 \pm 0.91 \mathrm{abc}$ & $1.28 \pm 0.23 \mathrm{def}$ & $12.96 \pm 2.32 \mathrm{bcd}$ \\
TOX 3145 & $63.42 \pm 0.04 \mathrm{f}$ & $67.66 \pm 0.16 \mathrm{f}$ & $74.02 \pm 1.14 \mathrm{~g}$ & $0.66 \pm 0.16 \mathrm{fg}$ & $23.61 \pm 2.32 \mathrm{a}$ \\
NERICA- 3 & $73.76 \pm 0.36 \mathrm{c}$ & $76.90 \pm 0.43 \mathrm{c}$ & $83.56 \pm 0.47 \mathrm{e}$ & $0.62 \pm 0.12 \mathrm{fg}$ & $12.46 \pm 0.17 \mathrm{~cd}$ \\
Local & & & & & $18.57 \pm 4.34 \mathrm{ab}$ \\
Kwandala & $75.88 \pm 0.06 \mathrm{~b}$ & $79.31 \pm 0.02 \mathrm{~b}$ & $87.87 \pm 0.49 \mathrm{abc}$ & $2.00 \pm 0.26 \mathrm{bcd}$ & $16.26 \pm 3.77 \mathrm{bc}$ \\
Yardass & $76.89 \pm 0.73 \mathrm{ab}$ & $80.81 \pm 0.30 \mathrm{a}$ & $87.80 \pm 0.28 \mathrm{bc}$ & $2.34 \pm 0.43 \mathrm{ab}$ & \\
\hline
\end{tabular}




\begin{tabular}{llllll}
\hline Jeep & $77.46 \pm 0.21 \mathrm{ab}$ & $80.75 \pm 0.16 \mathrm{a}$ & $86.87 \pm 0.51 \mathrm{~cd}$ & $1.38 \pm 0.13 \mathrm{def}$ & $13.39 \pm 3.05 \mathrm{bcd}$ \\
Jamila & $65.72 \pm 0.47 \mathrm{~d}$ & $70.34 \pm 0.85 \mathrm{~d}$ & $79.66 \pm 0.23 \mathrm{f}$ & $2.90 \pm 0.78 \mathrm{a}$ & $16.71 \pm 3.38 \mathrm{bc}$ \\
Panter & $76.84 \pm 0.37 \mathrm{ab}$ & $80.00 \pm 0.28 \mathrm{ab}$ & $85.47 \pm 0.64 \mathrm{ed}$ & $0.33 \pm 0.08 \mathrm{~g}$ & $11.74 \pm 1.07 \mathrm{~cd}$ \\
Tianan & $65.21 \pm 0.30 \mathrm{ed}$ & $69.86 \pm 0.30 \mathrm{ed}$ & $72.03 \pm 0.39 \mathrm{~g}$ & $1.21 \pm 0.09 \mathrm{ef}$ & $13.68 \pm 0.97 \mathrm{bcd}$ \\
\hline
\end{tabular}

Mean \pm SD values within same column followed by same letters are not significantly different $(\mathrm{P}>0.05)$

Table 2. Comparison of gelatinization parameters and amylose content between improved and local varieties

\begin{tabular}{lllll}
\hline Parameters & Local & Improved & T-value & P-value \\
\hline To $\left({ }^{\circ} \mathrm{C}\right)$ & $73.00 \pm 5.60$ & $70.88 \pm 6.75$ & -0.86 & 0.09 \\
Tp $\left({ }^{\circ} \mathrm{C}\right)$ & $76.84 \pm 5.02$ & $75.06 \pm 6.03$ & -0.81 & 0.14 \\
$\mathrm{Tc}\left({ }^{\circ} \mathrm{C}\right)$ & $83.28 \pm 6.02$ & $83.21 \pm 6.13$ & -0.03 & 0.81 \\
$\Delta \mathrm{H}(\mathrm{J} / \mathrm{g})$ & $1.69 \pm 0.92$ & $1.42 \pm 0.72$ & -0.86 & 0.53 \\
Amylose $(\%)$ & $15.06 \pm 3.31$ & $15.50 \pm 4.79$ & 0.27 & 0.30 \\
\hline
\end{tabular}

$\mathrm{P}>0.05$ is not significant

The comparison between improved and local varieties in gelatinization properties and amylose content is presented in Table 2. Local varieties showed higher values for onset temperature $\left(73.00\right.$ vs. $\left.70.88{ }^{\circ} \mathrm{C}\right)$, peak temperatures $(76$. 48 vs. $\left.74.06{ }^{\circ} \mathrm{C}\right)$, conclusion temperature (83.23 vs. $\left.83.21^{\circ} \mathrm{C}\right)$ and enthalpy (1.69 vs. $\left.1.42 \mathrm{~J} / \mathrm{g}\right)$ than the improved varieties. The mean value for amylose content among improved varieties (15.50\%) was higher compared to local varieties $(15.06 \%)$. The P-values presented in Table 2 indicated statistical similarity in parameters between the two groups of rice varieties. However, observation of variation in values for thermal properties and amylose content between improved and local varieties was very weak and insignificant $(\mathrm{P}>0.05)$. This finding indicated similarity among these rice varieties in thermal properties and in amylose content.

Table 3. Correlation Coefficient (r) between gelatinization parameters and amylose content of samples.

\begin{tabular}{llllll}
\hline $\begin{array}{l}\text { Parameter } \\
\text { s }\end{array}$ & To $\left({ }^{\circ} \mathbf{C}\right)$ & $\begin{array}{l}\mathbf{T p} \\
\left({ }^{\circ} \mathbf{C}\right)\end{array}$ & $\begin{array}{l}\mathbf{T c} \\
\left({ }^{\circ} \mathbf{C}\right)\end{array}$ & $\begin{array}{l}\Delta \mathbf{H} \\
(\mathbf{J} / \mathbf{g})\end{array}$ & $\begin{array}{l}\text { Amylose } \\
(\%)\end{array}$ \\
\hline $\begin{array}{l}\mathrm{To}\left({ }^{\circ} \mathrm{C}\right) \\
\mathrm{Tp}\left({ }^{\circ} \mathrm{C}\right)\end{array}$ & $\begin{array}{l}0.994 * \\
\end{array}$ & 1 & & & \\
& $*$ & & & & \\
$\mathrm{Tc}\left({ }^{\circ} \mathrm{C}\right)$ & $0.902 *$ & $0.923 *$ & 1 & & \\
& $*$ & $*$ & & & \\
$\begin{array}{l}\Delta \mathrm{H}(\mathrm{J} / \mathrm{g}) \\
\text { Amylose }\end{array}$ & -0.183 & -0.114 & -0.097 & 1 & \\
$(\%)$ & -0.215 & -0.226 & -0.206 & -0.080 & 1 \\
\hline
\end{tabular}

** Correlation is significant at 0.01 level.

The relationship between gelatinization parameters and amylose content is shown in Table 3. The onset, peak and conclusion temperatures were highly and positively correlated $(\mathrm{P}<0.01)$. The correlation between peak temperature with onset and conclusion temperatures were $\mathrm{r}=0.994$ and 0.923 , respectively. The enthalpy and amylose content had inverse and weak correlation with gelatinization temperatures $(\mathrm{P}>0.05)$. However, positive relationship of amylose with gelatinization properties had been described previously $[10,11,13,26]$.

Multivariate analysis was applied by average linkage clustering to establish similarities in gelatinization properties among samples. Figure 3 presents the similarities among the 13 samples into four major clusters. The first and third clusters comprised only one variety (TOX 3145 and NERICA-3, respectively). The second group contained four varieties (Tianan, Jamila, FARO 52 and FARO 44) while fourth cluster comprised seven varieties (Yardass, Kwandala, FARO 60, FARO 57, Panter, Jeep, FARO 61). TOX 3145 and NERIAC-3 indicated diverse thermal characteristics from the other rice samples.

The distinct characteristic of TOX 3145 from the other samples could be explained by its low onset, peak, conclusion temperatures, enthalpy and highest amylose content.

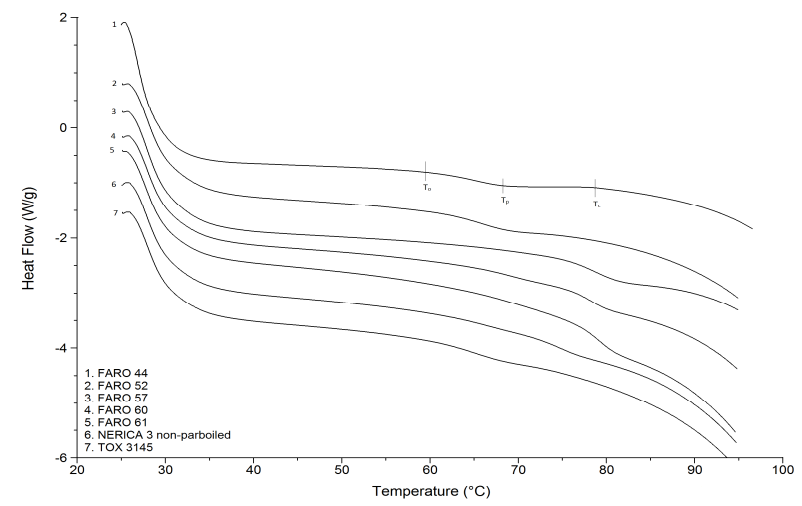

Figure 1. The gelatinization endotherm curves of seven improved varieties of non-parboiled rice as determined by differential scanning calorimetry (DSC).

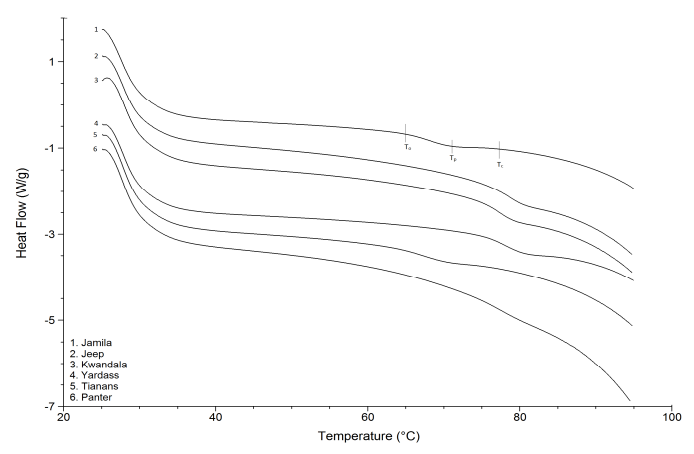

Figure 2. The gelatinization endotherm curves of six local varieties of non-parboiled rice as determined by differential scanning calorimetry (DSC). 


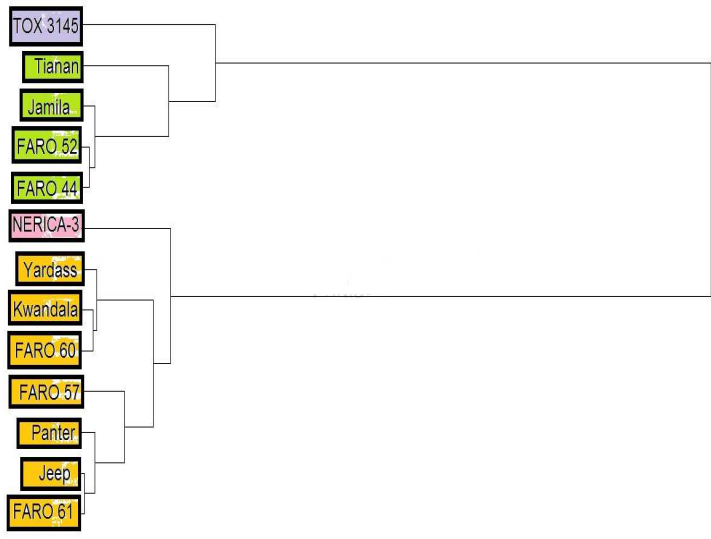

Figure 3. Dendrogram based on gelatinization characteristics and amylose content.

\section{Conclusion}

This study provides information on gelatinization properties and amylose contents of rice samples from Cameroun and Nigeria. The local varieties had higher onset and peak gelatinization temperatures than the improved varieties. The enthalpy levels were generally low among samples. A significant and positive correlation was observed among onset temperature, peak and conclusion temperatures while amylose was inversely related to all gelatinization parameters.

There is need for further study on influence of factors such as starch structures, nutritional composition on the gelatinization properties of these milled rice.

\section{References}

[1] Olembo, N., M'mboyi, F. and Oyugi, K. (2010). Success Stories in Crop Improvement in Africa: The Case of Rice in Sub-Saharan Africa. African Biotechnology Stakeholders Forum (ABSF), Nairobi, Kenya.

[2] WARDA: West Africa Rice Development Association (2004). Annual report. 2002-2003. The Africa Rice Center, Bouake', Cote D'ivoire, http://www.Warda.Org. (retrieved, $13^{\text {th }}$ August 2007).

[3] Fofana, M., Futakuchi, K., Manful, J., Bokossa, Y.I., Dossou, J. and Bleoussi, R. (2011). Rice grain quality: A comparison of imported varieties, local varieties with new varieties adopted in Benin. Food control, 22(12), 1821-1825.

[4] Traore, K., McClung, A.M., Fjellstrom, R. and Futakuchi, K. (2011). Diversity in grain physico-chemical characteristics of West African rice, including NERICA genotypes, as compared to cultivars from the United States of America. International Research Journal of Agricultural Science and Soil Science,1(10), 435-448.

[5] Kishine, M., Suzuki, K., Nakamura, S. and Ohtsubo, K.I. (2008). Grain qualities and their genetic derivation of 7 new rice for Africa (NERICA) varieties. Journal of agricultural and food chemistry, 56(12), 4605-4610.
[6] Lawal, O.S., Lapasin, R., Bellich, B., Olayiwola, T.O., Cesaro, A., Yoshimura, M. and Nishinari, K. (2011). Rheology and functional properties of starches isolated from five improved rice varieties from West Africa. Food Hydrocolloids, 25 (7), 1785-1792.

[7] Delcour, J.A., Bruneel, C., Derde, L.J., Gomand, S.V., Pareyt, B., Putseys, J.A., Wilderjans, E.and Lamberts, L. (2010). Fate of starch in food processing: from raw materials to final food products. Food Science and Technology, 1, 87-111.

[8] Bao, JS, Sun, M, Zhu, LH and Corke, H. (2004). Analysis of quantitative trait loci for some starch properties of rice (Oryzasativa L.): thermal properties, gel texture and swelling volume. Journal of Cereal Science, 39 (3), 379385 .

[9] Tribess, T., Hernández-Uribe, J., Méndez-Montealvo, M., Menezes, E., Bello-Perez, L. and Tadini, C. (2009). Thermal properties and resistant starch content of green banana flour $(<\mathrm{i}>$ Musa cavendishii $</ \mathrm{i}>$ ) produced at different drying conditions. LWT-Food Science and Technology, 42(5),10221025.

[10] Hermansson, M. and Svegmark, K. (1996). Developments in the understanding of starch functionality. Trends in Food Science and Technology,7, 345-353.

[11] Varavinit, S., Shobsngob, S., Varanyanond, W., Chinachoti, P. and Naivikul, O. (2003). Effect of amylose content on gelatinization, retrogradation and pasting properties of flours from different cultivars of Thai rice. Starch-Stärke, 55(9), 410-415.

[12] Tester, R. F. and Morrison, W. R. (1990). Swelling and gelatinization of cereal starches. Effects of amylopectin, amylose and lipids. Cereal Chemistry, 67, 551-557.

[13] Park, I.M., Ibáñez, A.M., Zhong, F. and Shoemaker, C.F. (2007). Gelatinization and Pasting Properties of Waxy and Non-waxy Rice Starches. Starch-Stärke, 59(8), 388-396.

[14] Normand, F. L., and W. E. Marshall. (1989). Differential scanning calorimetry of whole milled rice and milled rice flour. Cereal Chemistry, 66 (4), 317-320.

[15] Lim, S.T., Lee, J.H., Shin, D.H. and Lim, H.S. (1999). Comparison of protein extraction solutions for rice starch isolation and effects of residual protein content on starch pasting properties. Starch-Stärke, 51, 410-415.

[16] Billiaderis, C.G., Page, C.M., Maurice, T.J., and Juliano, B.O. 1986. Thermal characterization of rice starch: A polymeric approach to phase transition of granular starch, Journal of Agricultural and Food Chemistry, 34, 6-14.

[17] Hoover, R. and Ratnayake, W. (2001). Determination of total amylose content of starch. Current protocols in food analytical chemistry, Wiley, New York (2001). Section E, Unit 2-3.

[18] Fan, J., Marks, B. P., Daniels, M. J. and Siebenmorgen, T. J. (1999). Effects of postharvest operations on the gelatinization and retrogradation properties of long-grain rice. Transactions of the ASABE, 42(3), 727-731.

[19] Zhu, L. J., Liu,Q. Q.,Wilson, J. D., Gu,M. H. and Shi, Y. C. (2011). "Digestibility and physicochemical properties of rice (Oryza sativa L.) flours and starches differing in amylose 
content." Carbohydrate Polymers, 86(4),1751-1759.

[20] Saif, S., Lan, Y. and Sweat, V. (2003). Gelatinization properties of rice flour. International Journal of Food Properties, 6(3), 531-542.

[21] Jayakody, L., Hoover, R., Liu, Q. and Donner, E. (2007). Studies on tuber starches. II. Molecular structure, composition and physicochemical properties of yam (Dioscorea sp.) starched grown in Sri Lanka. Carbohydrate polymers, 69(1), $148-163$.

[22] Bocevska, M., Aldabas, I., Andreevska, D. and Ilieva, V. (2009). Gelatinization behavior of grains and flour in relation to physico-chemical properties of milled rice (oryza sativa l.). Journal of Food Quality, 32(1), 108-124.

[23] Singh, J., Dartois, A. and Kaur, L. (2010). Starch digestibility in food matrix: a review. Trends in Food Science and Technology, 21(4), 168-180.

[24] Vlachos, A. and Arvanitoyannis, I.S. (2008). A review of rice authenticity/adulteration methods and results. Critical reviews in Food Science and Nutrition, 48(6), 553-598.

[25] Frei, M., Siddhuraju, P. and Becker, K. (2003). Studies on the in vitro starch digestibility and the glycemic index of six different indigenous rice cultivars from the Philippines. Food Chemistry, 83(3), 395-402.

[26] Jane, J., Chen, Y., Lee, L., McPherson, A., Wong, K., Radosavljevic, M. and Kasemsuwan, T. (1999). Effects of Amylopectin Branch Chain Length and Amylose Content on the Gelatinization and Pasting Properties of Starch 1. Cereal Chemistry, 76(5), 629-637. 